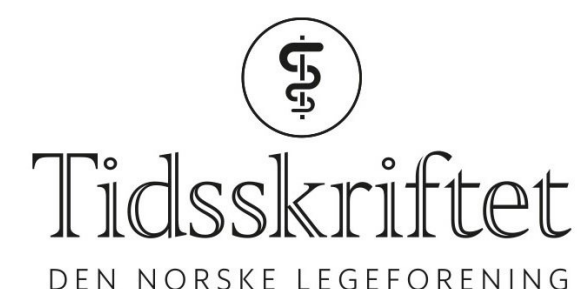

DEN NORSKE LEGEFORENING

\title{
Rettelse: Non-invasiv prenatal test (NIPT)
}

RETTELSE

TORBJØRN MOE EGGEBØ

Tidsskr Nor Legeforen 2020; 140. doi: 10.4045/tidsskr.20.0145.

I artikkelen skal det stå: Hvis den ble brukt som primærtest til alle gravide, dvs. rundt 55000 hvert år, ville 271 av de estimerte 275 tilfellene bli oppdaget, men i tillegg ville vi forvente 230 falskt positive prøver.

Vi beklager feilen, den er rettet på nett.

Publisert: 25. mai 2020. Tidsskr Nor Legeforen. DOI: 10.4045/tidsskr.20.0467

(C) Tidsskrift for Den norske legeforening 2020. Lastet ned fra tidsskriftet.no 